\title{
In-Situ Measurements of Carbon Stable Isotopes Ratio in Karstic Caves by FTIR Spectroscopy
}

\author{
Ira Litvak, Yaakov Anker, and Haim Cohen
}

\begin{abstract}
Carbon stable isotope ratios measurement serves as an important implement for environmental geochemical processes study. While Mass spectrometry is commonly used for the task, FTIR (Fourier Transform Infra-Red) spectroscopy has the potential for determining these isotopic ratios with the advantage of simple in-situ measurements. Online analysis enables continuous processes monitoring and decreases sampling errors, caused by the sampling and the laboratory analysis procedures (e.g. for measurement in the mass spectrometer).

Variance in carbon stable isotope ratios are results of waterrock interactions, phase transitions, changes in ambient temperature and humidity, biochemical reactions and more. In this study carbon isotope ratios were measured using FTIR spectrophotometer in both field and in laboratory conditions and corroboration of the analysis validity was done by Mass spectrometer measurements.

The research results suggest that: Carbon isotope ratio $\left({ }^{13} \mathrm{C} /{ }^{12} \mathrm{C}\right)$ may be determined by FTIR spectroscopy of the $\mathrm{CO}_{2}$ released from water samples under acidic conditions.

As a case-study, FTIR analysis was used for characterizing phase transitions and water-rock interactions of runoff infiltrating a cave. By profiling the stable isotope systems, we have found that the $\delta^{13} \mathrm{C}$ values, which were calculated using FTIR showed sufficient agreement to those of the Mass Spectrometer measurements.

A case study analyzing water samples from karstic cave (Sif cave, Israel), verified that: (a) On line determination of water ${ }^{13} \mathrm{C} /{ }^{12} \mathrm{C}$ ratio can be carried out with the portable FTIR spectrometer, hence can be taken to field measurements as preformed in the Sif cave. (b) The $\mathrm{C}$ concentration sensitivity achieved was $7 \%$ in $\delta$ values, which is applicable for most carbon stable isotopes applications.
\end{abstract}

Index Terms-C13, carbon isotopes, FTIR, in-situ measurements.

\section{INTRODUCTION}

Water isotopic content is the subject of many environmental studies as it gives important information about their origin and history. Any atmospheric water contains certain amount of dissolved carbon dioxide. Thus oxygen, hydrogen and carbon through its various species

Manuscript received April 19, 2018; revised May 24, 2018.

Ira Litvak is with the he Melbourne University Department of Infrastructure Engineering, Australia (e-mail: irachkalitvak@gmail.com).

Dr. Yaakov Anker is with the Department of Chemical and Material Engineering at the Ariel University and the Environmental Department of the Eastern Israel Regional R\&D Center, Israel (e-mail: kobia@ariel.ac.il).

Prof. Haim Cohen is with the Department of Biological Chemistry (Faculty of Natural Sciences) at Ariel University and the Department of Chemistry at Ben-Gurion University of the Negev in Beer Sheba, Israel (email: hcohen@ariel.ac.il).
$\left(\mathrm{CO}_{2}, \mathrm{HCO}_{3}^{-} \& \mathrm{CO}_{3}^{--}\right)$are commonly used for isotopic characterization of natural water [1]. Carbon has got two naturally occurring stable isotope, ${ }^{12} \mathrm{C}$ and ${ }^{13} \mathrm{C}$ with the abundance of $98.9 \%$ and $1.1 \%$ respectively $\left({ }^{13} \mathrm{C} /{ }^{12} \mathrm{C}\right.$ $\sim 0.011$ ).

Most geochemical processes are precipitation-dissolution reactions rather than oxidation-reduction processes. For example, Calcium Carbonate dissolution-sedimentation process is a chemical reactions but not an oxidationreduction process [2]. Thus, the reaction rates are slightly different in the various carbon isotopes, or if equilibrium is established isotopes partition themselves differently between products and reactants [3].

The natural stable carbon isotope equilibrium occurs usually via three processes: inorganic-chemical, organicbiological and combined effect. The inorganic carbonate system is comprised of multiple chemical species linked by a series of equilibria: $\mathrm{CO}_{2}-\mathrm{H}_{2} \mathrm{O}-\mathrm{H}_{2} \mathrm{CO}_{3}-\mathrm{CaCO}_{3}$. The organic process of carbon isotope fractionations occurs during photosynthesis or respiration and depends on the partial $\mathrm{CO}_{2}$ pressure of the system [4].

The dissolution of $\mathrm{CO}_{2}$ or it's degassing processes occurs through several reactions [5]:

$$
\begin{aligned}
& \mathrm{H}_{2} \mathrm{O}+\mathrm{CO}_{2} \rightarrow \mathrm{H}_{2} \mathrm{O} \cdot \mathrm{CO}_{2} \text { (complex) } \\
& \mathrm{H}_{2} \mathrm{CO}_{3} \leftrightarrow \mathrm{HCO}_{3(\mathrm{aq})}^{-}+\mathrm{H}^{+} \quad \mathrm{p} K_{1}=6.36 \\
& \mathrm{HCO}_{3}{ }^{-} \text {(aq) } \leftrightarrow \mathrm{CO}_{3}{ }^{2-}{ }_{(\mathrm{aq})}+\mathrm{H}^{+} \mathrm{p} K_{2}=10.33
\end{aligned}
$$

Precipitation of calcite occurs via:

$$
\mathrm{Ca}\left(\mathrm{HCO}_{3}\right)_{2} \rightarrow \mathrm{CaCO}_{3(\mathrm{~s})}+\mathrm{CO}_{2(\mathrm{~g})}+\mathrm{H}_{2} \mathrm{O}
$$

${ }^{13} \mathrm{C}$ delta values $(\delta)$ are calculated using the following equation:

$$
\delta(\text { in } \% \text { o })=\left(\frac{(\text { s sample })}{(\text { R standard })}-1\right) 1000
$$

where " $R$ " represents the ratio between the heavy isotope $\left({ }^{13} \mathrm{C}\right)$ and the light isotope $\left({ }^{12} \mathrm{C}\right)$ in the sample and in the standard.

Different $\delta$ Values of ${ }^{13} \mathrm{C}$ are typical for different carbon sources; for example fresh-water carbonate (which is the carbon source type chosen as the case-study) are in typical range values of $(-20)-(+14) \%$ and groundwater $\mathrm{HCO}_{3}{ }^{-}$in within values range of $(-27)-(+13) \%$ and marine carbonate type presents values of $(-2)-(+3) \%$ C3 type plants typical values range are of $(-30)-(-20) \%$ and C4 type plants are in the range of $(-15)-(-10) \%$ [6].

The common practice of carbon isotopic abundance determination is Mass spectrometry (MS) [7], [8], however 
this research examines the potential of FTIR (Fourier Transform Infra-Red) spectroscopy for these isotopic measurements.

Our hypothesis is that by using a portable FTIR device it is possible to perform in-situ measurements, so it will not be necessary to collect, treat and preserve the samples. The benefits of such method are delineation of continuous processes and reduction of analysis errors, affiliated to the sampling and MS sample preparation procedures. As in-situ measurements are conducted at the site place, there is no need to stabilize the temperature and (partial) pressure(s) of the FTIR spectrometer conditions, which might lead to potentially large errors introduced by variations in the line intensities due to Boltzmann changes owing to ground level conditions. Moreover, FTIR does not require high vacuum system as the MS does, it is smaller in size and relatively inexpensive. In addition, the infrared spectra measurement procedure is fast and easy and is already replacing MS in other measurements types [9]. Other new technologies for stable isotopes measurements, such as CRDS lasers [10][13]; are yet far from cost effective nor simple to operate, when compared to FTIR. As field measurements complexity within a cave or in similar terrains demands convenient procedure, most measurements procedures are hardly applicable.

In this perspective, the main goal of the research is to develop a simple, in-situ measurement method for portable FTIR, enabling stable carbon isotopes ratio $\left({ }^{13} \mathrm{C} /{ }^{12} \mathrm{C}\right)$ determination in water. The method testing case-study, investigated the Sif karstic cave geochemical system. Online measurement performed included water samples from three locations (noted as 1-3) within the cave, which were directly collected and measured in-situ.

\section{MATERIAL AND METHODS}

\section{A. Case Study Site-Sif Cave in-Situ Sampling}

The Sif cave is located in the central part of Israel and was formed in telogenetic mature dolomitic limestone of Weradim Formation, Cenomanian (late Cretaceous) age, in the upper part of the carbonate Judea Group. The dissolution process of the dolostone \{carbonate mineral composed of calcium magnesium carbonate $\}$ is slow and occurs via the chemical reaction:

$$
\mathrm{CaMg}\left(\mathrm{CO}_{3}\right)_{2(\mathrm{~s})}+2 \mathrm{H}_{2} \mathrm{CO}_{3} \rightarrow \mathrm{Ca}\left(\mathrm{HCO}_{3}\right)_{2}+\mathrm{Mg}\left(\mathrm{HCO}_{3}\right)_{2}
$$

Runoff percolating through the soil dissolves carbon dioxide that is released once water drips into a cave; this process is responsible for precipitation of speleothems and to the slightly different cave atmosphere (in reference to the surface).

The water were collected by three large plastic (polyvinyl chloride - PVC) sheets transferred hundreds of drips from three different areas in the cave denoted as 1-3 [14]. The sheets surface areas are: Site 1: $17 \mathrm{~m}^{2}$, Site 2: $56 \mathrm{~m}^{2}$, and Site 3: $46 \mathrm{~m}^{2}$. From the sheets water is flowing into three separate barrels and the samples are collected from the barrels. The PET bottles which contain the water samples for laboratory measurements (MS and for FTIR reference) were filled to the top with water (without free gas phase). The overflow filling insures that no exchange with atmospheric $\mathrm{CO}_{2}$ will take place. The samples are kept cooled at $4^{\circ} \mathrm{C}$ [15].

\section{B. Materials \\ 1) Samples}

Standards samples were prepared using Calcite (a-b), Sodium carbonate and pure $\mathrm{CO}_{2}$ gas. Calcite from two sources was used as a standard (a) or as internal standards (b). (a) IAEA-CO-8, Calcite reference material IAEA-CO-8 is a natural carbonatite originating from Schelingen at the Kaiserstuhl, Germany. (b) Fine $\mathrm{CaCO}_{3}$ powder from local limestone of the Weradim formation (Judea group, Israel). Sodium carbonate, $\mathrm{Na}_{2} \mathrm{CO}_{3} \mathrm{AR}$ grade (supplied by Merck), has been used as well as an internal standard. $\mathrm{CO}_{2}$ gas, $\mathrm{CP}$ grade was taken from a gas bottle (supplied by Oxygen and Argon Works LTD) and used as an internal standard. All powders were dissolved with Ultra-Pure distilled Water (UPDI) from a Dow Water \& Process Solutions ion exchange system. The water resistance was 18.2 Mohm $/ \mathrm{cm}$ at $25^{\circ} \mathrm{C}$, with TOC Values lower than 5ppb.

\section{2) MS measurements}

A BALZERS model QMG421 quadrupole Mass Spectrometer has been used as a reference unit for the determination of stable isotopic content. The analysis of the $\mathrm{CO}_{2}$ yields a peak at mass $44 \mathrm{amu}$ which originates from ${ }^{12} \mathrm{C}^{16} \mathrm{O}_{2}{ }^{+}$ion and a peak at mass $45 \mathrm{amu}$ which originates from ${ }^{13} \mathrm{C}^{16} \mathrm{O}_{2}{ }^{+}$ion. Sample solution of $20 \mathrm{ml}$ filled the sampling reactor through septa and frozen at $77 \mathrm{~K}$ (using liquid Nitrogen), after that the air above the sample was pumped via a vacuum line. Concentrated Hydrochloric acid was injected $(1 \mathrm{~mL})$ via the septa, and was frozen again (air residue was pumped out). Following this step, the frozen sample was melted by heating to room temperature. The reaction between carbonates in the sample and acid released $\mathrm{CO}_{2}$ gas to the reactor. Finally, the gas sample was injected to the MS for analysis at $5 \times 10^{-6}$ mbar, via a special leak valve. The background measurement was carried out at high vacuum of $7 \times 10^{-8}$ mbar.

\section{3) FTIR measurements}

The FTIR instrument used in this study was Agilent Technologies; model Cary 630 with a transmission unit accessory. The sample preparation both in-situ and in the laboratory was similar to the procedure for the MS measurements. The first step in the measurement procedure is to eliminate the $\sim 400 \mathrm{ppm}$ atmospheric $\mathrm{CO}_{2}$ by setting it as background. First the FTIR gas cell must be emptied, and then opened to atmospheric air, closed and measured as background. In the next step, a glass sampling bulb with a magnet was filled with $80 \mathrm{~mL}$ sample solution, and attached to an empty FTIR gas cell (Fig. 1 in the insert). Concentrated Hydrochloric acid was added $(4 \mathrm{~mL})$ and the solution was stirred for 1-2 minutes (The valve between the cell and the reactor is closed). The released carbon dioxide was transported from the sampling bulb to the cell (by opening a connecting valve) - the $\mathrm{CO}_{2}$ degassing from the solution lasts between two to three minutes. The cell was detached from the reactor (all the cell valves were closed) 
and the FTIR was operated using $2 \mathrm{~cm}^{-1}$ resolution, 100 scans (for background and sample measurements). The FTIR detector was of deuterated triglycine sulfate (DTGS) and the beam splitter of $\mathrm{KBr}$.

The system which was prepared and used for in-situ field measurements (in Sif cave) is presented in Fig. 1. From left to right it can be noticed: (a) A gas cell attached to a (b) Sampling reactor which is connected through a reinforced PP black pipeline via a diaphragm vacuum pump to (c) the FTIR spectrometer, which is operated by an Acer laptop computer.

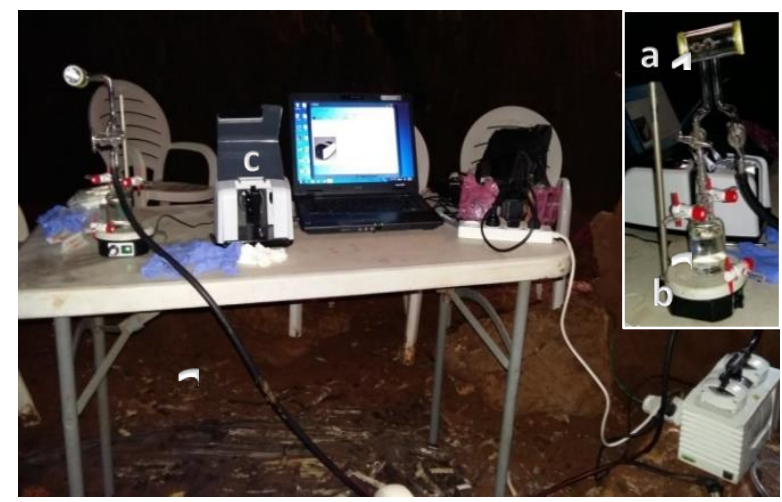

Fig. 1. In-situ (Sif Cave) sampling system for gas analysis in the FTIR (In the insert: a. Gas cell; b. Sampling reactor).

\section{RESULTS AND DISCUSSION}

While $\mathrm{CO}_{2}{ }^{13} \mathrm{C}$ isotopes abundance measurements by MS are common practice, it also demands special sampling procedure and the transportation of the sample to the laboratory for analysis. Both actions might result an inherent difference from the in-situ measured values [16]. As MS field applications techniques are complex and expensive, there are several IR spectroscopy based devices under ongoing development that are capable to perform insitu stable isotopes analysis [17].

The present study was aimed to develop and evaluate a FTIR spectroscopy based methodology for environmental isotopes analysis, conducted in field conditions. In most reported studies [18]-[20] carbonates ${ }^{13} \mathrm{C}$ abundance was determined from air samples in gaseous phase and the measurement procedure, data calculation and processing used complex instruments and multi-stage procedures, which are far more complicated than the method developed in the current study. As example, the Mohn et al. 2008 setting requires keeping the FTIR in an air conditioned trailer, oil-free vacuum pump for extracting the sample and also membrane pump and thermoelectric chiller. In comparission, the metodolgy presented here requires a simple portable FTIR device and a diaphragm vacuum pump to evacuate the gas cell for the previous in-situ measured sample. In addition, the pump can also be used for water trasformation from the water source to the sampling reactor. For the data calculation and processing Mohn et al. 2008 used PLS-based calibration strategy, Griffith et al. 2006 used classical least squares method and Vardag et al. 2015 used non-linear least squares using the program MALT; in the present study a simple calibration factor was applied, for correcting the FTIR results with the atomic weight values (based on MS data).

The procedure described in this paper enables "real world" scenario assessment. The system evaluated here as an example included $\mathrm{CO}_{2}$ that was extracted by acidification from water samples, taken in the karstic Sif cave, The $\mathrm{CO}_{2}$ that was released from the solution with strong acid $(\mathrm{HCl})$, demonstrated relatively in high concentrations (almost 60 times higher than its concentration in air), which ensures an accurate and sensitive FTIR stable carbon isotope analysis.

\section{A. FTIR Data Processing - Calibration Factor Calculation}

The typical $\mathrm{CO}_{2}$ IR spectrum given in Fig. 2, shows doublet peak right and left branches at 2,345 and 2,365 $\mathrm{cm}^{-1}$ respectively, representing ${ }^{12} \mathrm{CO}_{2}$ absorbance and a small peak at 2,275 $\mathrm{cm}^{-1}$ represents the R-branch of the ${ }^{13} \mathrm{CO}_{2}$ absorbance. The L-branch ${ }^{13} \mathrm{CO}_{2}$ absorbance is masked underneath the ${ }^{12} \mathrm{CO}_{2} \mathrm{R}$-branch peak, which introduces difficulty to the ${ }^{13} \mathrm{C} /{ }^{12} \mathrm{C}$ ratio calculation via peak area. While peak area ratio calculation is usually more accurate and commonly used, in this case due to the masking of the ${ }^{13} \mathrm{CO}_{2} \mathrm{~L}$-branch, this method cannot be used. Owing to that, the height ratio of the relevant peaks was chosen for the calculations. In order to determine a calibration factor for the FTIR it was needed to establish which wavelength is most representative. For those purpose five potential wavelengths points have been tagged with numbers 1-5 for further evaluation.

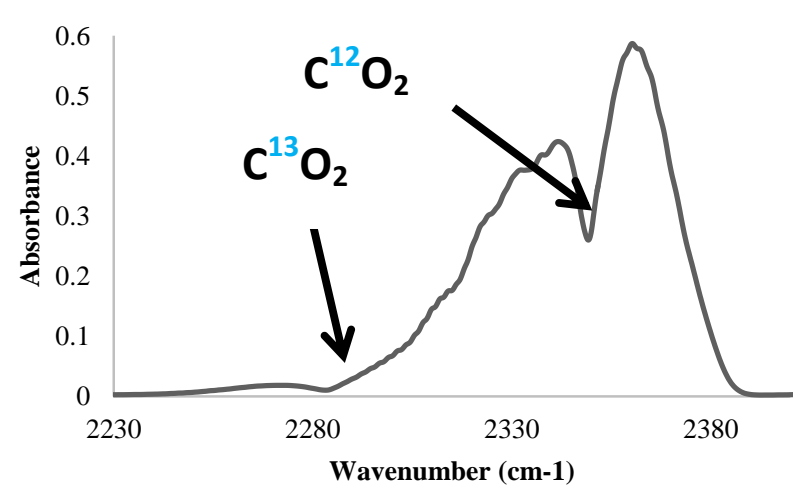

Fig. 2. FTIR Spectrum of $\mathrm{CO}_{2}$ gas representing isotopes of ${ }^{13} \mathrm{C}$ and ${ }^{12} \mathrm{C}$ $\left(\lambda_{1}=2,361 \mathrm{~cm}^{-1}, \lambda_{2}=2,343 \mathrm{~cm}^{-1}, \lambda_{3}=2,273 \mathrm{~cm}^{-1}, \lambda_{4}=2,350 \mathrm{~cm}^{-1}, \lambda_{5}=2,285\right.$ $\left.\mathrm{cm}^{-1}\right)$.

TABLE I: 13C RATIOS FROM THE MS OF THE 3 CARBON SOURCES AND IAEA STANDARD

\begin{tabular}{lllll}
\multicolumn{5}{c}{ IAEA STANDARD } \\
\hline $\mathrm{Na}_{2} \mathrm{CO}_{3}$ & $\begin{array}{l}\mathrm{CaCO}_{3} \\
\text { Weradim }\end{array}$ & $\mathbf{C O}_{2}$ (Gas) & $\begin{array}{l}\mathrm{CaCO}_{3} \\
\text { IAEA } \\
\text { (Standard) }\end{array}$ \\
\hline $\begin{array}{l}\text { MS } \\
\text { ratio }\end{array}$ & 0.0121 & 0.0119 & 0.0115 & 0.0117 \\
\hline
\end{tabular}

In order to calculate the FTIR samples calibration factor, data from the MS was used as standard. The MS calculations of ${ }^{13} \mathrm{CO}_{2} /{ }^{12} \mathrm{CO}_{2}$ ratio were done by dividing the signal in mass $45 \mathrm{amu}$ to the signal in mass $44 \mathrm{amu}$. The results of the ratio values from the MS (MS ratio) are given in Table I for 3 different sources of carbon: $\mathrm{Na}_{2} \mathrm{CO}_{3}, \mathrm{CaCO}_{3}$ Weradim, $\mathrm{CO}_{2}$ (Gas) and $\mathrm{CaCO}_{3}$ IAEA (standard), the results of the ${ }^{13} \mathrm{CO}_{2} /{ }^{12} \mathrm{CO}_{2}$ ratio were in the range of 


\section{$0.0115-0.0121$}

In order to choose the best peak ratio among the five $\lambda$, we estimated which ratio will provide the best calibration factor. The indication that a ratio is optimal was by dividing each calibration factor of the three different carbon sources with each other and determining which one is approaching the value of 1 . The calibration factor was calculated by dividing the absorbance value at a certain $\lambda$ in the sample (carbon source) and in the standard (IAEA) - this is noted as $\alpha^{\text {FTIR }}$, then dividing it with the $\boldsymbol{\alpha}^{M S}-$ which is the ratio of the signals $45 / 44$ in the sample and the standard in the
MS measurements (Table I).

For example of best ratio picking, this procedure was preliminary carried out in the laboratory on Weradim $\mathrm{CaCO}_{3}$ powder and on $\mathrm{CO}_{2}$ Gas standard (Table II). The same method was used with IAEA $\mathrm{CaCO}_{3}$ powder standard, in order to calculate the laboratory standard. The result that gave the best value of $f_{i} / f_{j}=1$ has been used for the calculation of the calibration factor. Thus the measurements at $\lambda_{2}=2,343 \mathrm{~cm}^{-1}$ and $\lambda_{3}=2,273 \mathrm{~cm}^{-1}$ has been used for the ${ }^{13} \mathrm{C} /{ }^{12} \mathrm{C}$ determination $[\lambda(2 / 3)]$.

TABLE II: EXAMPLE OF THE HEIGHT RATIO ${ }^{13} \mathrm{C}$ ISOTOPE CHOOSING $\left(\mathrm{CACO}_{3}\right.$ WeRAdIM AND CO $\left.\mathrm{CO}_{2} \mathrm{GAS}\right)$

\begin{tabular}{|c|c|c|c|c|c|c|c|}
\hline $\begin{array}{l}\text { Peaks } \\
\text { Ratio }\end{array}$ & $\begin{array}{c}\text { *1.1.1. } \\
\alpha^{\text {FTIR }} \\
\mathrm{CaCO}_{3} \\
\text { Weradim } \\
\end{array}$ & $\begin{array}{c}.1 .1 .2 . \\
* \alpha^{m S} \\
\mathbf{C a C O}_{3} \\
\text { Weradim } \\
\end{array}$ & $\begin{array}{c}\alpha^{F I I R} \\
\mathrm{CO}_{2} \text { Gas }\end{array}$ & $\begin{array}{l}\alpha^{M S} \\
\mathrm{CO}_{2} \\
\text { Gas }\end{array}$ & $\begin{array}{c}{ }^{* * * *} \mathrm{f} \\
\mathrm{CaCO}_{3} \\
\text { Weradim }\end{array}$ & $\underset{\text { Gas }}{\mathbf{f} \mathrm{CO}_{2}}$ & $\begin{array}{c}\mathrm{f} \\
\mathrm{CaCO}_{3} \\
\mathrm{Werad} \\
\mathrm{im} / \mathrm{f} \\
\mathrm{CO}_{2} \\
\mathrm{Gas}\end{array}$ \\
\hline$\lambda(\mathbf{1} / \mathbf{2})$ & $\begin{array}{l}0.979 \\
\end{array}$ & \multirow{10}{*}{1.017} & 0.998 & \multirow{10}{*}{0.983} & 1.039 & 0.985 & 1.055 \\
\hline$\lambda(\mathbf{1} / \mathbf{3})$ & 0.941 & & 0.958 & & 1.080 & 1.026 & 1.053 \\
\hline$\lambda(\mathbf{1} / \mathbf{4})$ & 1.043 & & 1.076 & & 0.975 & 0.913 & 1.067 \\
\hline$\lambda(\mathbf{1} / \mathbf{5})$ & 0.935 & & 0.797 & & 1.088 & 1.233 & 0.882 \\
\hline$\lambda(2 / 3)$ & 0.998 & & 0.966 & & 1.019 & 1.018 & 1.001 \\
\hline$\lambda(2 / 4)$ & 1.065 & & 1.078 & & 0.955 & 0.912 & 1.047 \\
\hline$\lambda(\mathbf{2} / \mathbf{5})$ & 0.956 & & 0.799 & & 1.064 & 1.230 & 0.865 \\
\hline$\lambda(\mathbf{3} / \mathbf{4})$ & 1.090 & & 1.109 & & 0.933 & 0.886 & 1.053 \\
\hline$\lambda(\mathbf{3} / \mathbf{5})$ & 0.993 & & 0.832 & & 1.025 & 1.181 & 0.867 \\
\hline$\lambda(\mathbf{4} / \mathbf{5})$ & 0.892 & & 0.737 & & 1.141 & 1.333 & 0.855 \\
\hline
\end{tabular}

$* * * \mathbf{f}=\alpha^{M S} / \alpha^{F T I R}$

As shown in Table II, the best $\mathrm{f}_{\mathrm{i}} / \mathrm{f}_{\mathrm{j}}$ value was $\lambda_{2}\left(2,345 \mathrm{~cm}^{-}\right.$ $\left.{ }^{1}\right)$ and $\lambda_{3}\left(2,275 \mathrm{~cm}^{-1}\right)$,

Once the best peak ratio was determined (meaning the closest $f_{i} / f_{j}=1$ ), calculation of the average calibration factor was done as explained in Table III. In order to establish the standard calibrated values the Calcite value was aligned to the IAEA-CO-8 standard [21]. For calibration of the FTIR measurements to the values that were determined by the MS method in the laboratory, a MS standard ratio (0.0117) was used for the calibration factor calculation (f) between the MS and FTIR (Table III). Moreover, $\delta$ values that was calculated for MS and for FTIR and was also compared with datasets from other studies for validation. $\delta$ calculation relayed in the MS on the ratio between the signals in mass 45 and $44 \mathrm{amu}$, in both the sample and the standard $\left(\alpha^{M S}\right)$; and for FTIR on the ratio between peaks 2 to 3 in both the sample and in the standard $\left(\alpha^{\text {FTIR }}\right)$, which was multiplied by the calibration factor (f). The sum of the results for all three carbon sources is presented in Table III.

Yet there is some variance between MS and FTIR values that might be consequence the FTIR ratio calculation procedure. Owing to peak overlapping the calculation relies on peak heights that do not reflects the entire impact of the two isotopes disparity, as area calculation do. In order to align this discrepancy the calibration factor that calculated from three unrelated carbon sources and was found to be: 1.017 (Table III).

TABLE III: CALCULATION OF CALIBRATION FACTOR (F) AND $\Delta$ FROM THE THREE CARBON SOURCES

\begin{tabular}{ccccc}
\hline $\begin{array}{c}\text { Name of } \\
\text { sample }\end{array}$ & f & $\begin{array}{c}\boldsymbol{\delta} \\
\text { FTIR } \\
\text { in \%o }\end{array}$ & $\begin{array}{c}\boldsymbol{\delta} \text { MS } \\
\text { in \%o }\end{array}$ & Error in \%o \\
\hline $\mathbf{C O}_{2}$ Gas & 1.018 & -17.28 & - & 0.190 \\
$\mathbf{N a}_{2} \mathbf{C O}_{3}$ & 1.016 & 36.05 & 34.19 & 1.866 \\
$\begin{array}{c}\text { CaCO } \\
\text { Weradim }\end{array}$ & 1.019 & 15.46 & 17.09 & 1.633 \\
$\begin{array}{c}\text { CaCO3 } \\
\text { IAEA } \\
\text { (standard) }\end{array}$ & & & & \\
Average & 1.017 & & & \\
\hline
\end{tabular}

B. $\boldsymbol{\delta} 13 \mathrm{C}$ of Dissolved Carbonate in Water Samples from Sif Cave: In-Situ and Laboratory Measurements

Samples from Sif cave were measured via the FTIR spectrophotometer as a portable on-line measurement system 
in the cave and in the laboratory and compared with the MS measurements. Since the comparison to the MS measurements was essential, the samples were collected on the 05.04.2017 in sampling vials and measured in both MS and FTIR on the next day. The water samples denoted 1, 2 and 3 represent the barrels, of which a sample was taken from. The FTIR spectra of the same sample measured in the cave (in-situ - Fig. 1). The values calculated for $\delta^{13} \mathrm{C}$ via the MS and FTIR (in-situ and laboratory measurements) methods are shown in Table IV. Each sample was measured in duplicates.

TABLE IV: EXAMPLE OF THE $\Delta^{13}$ C RESULTS FOR Sif CAVE SAMPLES - MS AND FTIR

\begin{tabular}{cccc}
\hline $\begin{array}{c}\text { Sample } \\
\text { name }\end{array}$ & $\begin{array}{c}\boldsymbol{\delta}^{13} \mathbf{C} \text { FTIR in-situ } \\
\text { in \%o }\end{array}$ & $\begin{array}{c}\boldsymbol{\delta}^{13} \mathbf{C} \text { FTIR in lab } \\
\text { in \%o }\end{array}$ & $\begin{array}{c}\boldsymbol{\delta}^{13} \mathbf{C} \text { MS } \\
\text { in \%o }\end{array}$ \\
\hline Sif 1 & -15.86 & -13.55 & -8.667 \\
Sif 2 & -10.84 & -5.488 & -6.005 \\
Sif 3 & -8.381 & -2.043 & -8.343 \\
\hline
\end{tabular}

The FTIR $\delta^{13} \mathrm{C}$ values measurements were with standard deviation of $\mp 3.113 \%$ for in-situ measurements and $\mp 4.820 \%$ for laboratory measurements. For MS measurements the standard deviation was $\mp 1.186 \%$. The differences between the two methods (FTIR in-situ compered to MS) showed deviation of $\mp 7.195 \%$ (Table IV and Table III), which might be consequence of different treatment procedure of the samples and also owing to equipment inaccuracies.

While different carbon sources are characterized by value ranges with gaps greater than 7\%o (e.g. marine carbonate and groundwater $\mathrm{HCO}_{3}^{-}$), there are also overlaps between other carbon sources (e.g. fresh-water carbonate and groundwater $\mathrm{HCO}_{3}{ }^{-}$) [6]. Although, MS measurement is yet more accurate than that with FTIR, by obtaining big enough dataset for the calibration factor (from both the MS and FTIR analysis) this gap can be overcome, resulting with a better and precise factor.

Moreover, since in-situ measurements prevents errors induced by sample transport and preparation the FTIR method can be even be superior to MS. Further potential improvement in the FTIR carbon isotopes ratio calculation can be achieved by advanced modelling that will enable absorption peaks area calculation, which may improve the accuracy and resemblance to MS methodology. The integration of laboratory and field works demonstrated that FTIR can be used for carbon ratio $\left({ }^{13} \mathrm{C} /{ }^{12} \mathrm{C}\right)$ analysis, not only in the laboratory but also in-situ. The new method is applicative for measurements of all types of water sources containing dissolved carbonates and can replace complicated MS measurements by applying calibration factor similar to the one found in this study.

\section{CONCLUSONS}

The goal of this study was to develop a simple low cost method for in-situ measurements of isotope ratio of ${ }^{13} \mathrm{C} /{ }^{12} \mathrm{C}$ by using simple and affordable FTIR spectrophotometer.
Calibration factor for FTIR analysis was calculated from three carbonate sources $(f=1.017)$. As case study, samples from Sif cave were analyzed on the FTIR and compared with MS analysis, which demonstrated differences of 7\%o in $\delta$ values. This work demonstrated how a portable FTIR device can be used for carbon ratio $\left({ }^{13} \mathrm{C} /{ }^{12} \mathrm{C}\right)$ analysis, not only in the laboratory but for field measurements. The new method is applicative for measurements of all types of water sources containing dissolved carbonates and can replace complicated MS measurements by applying the calibration factor found in this study. Since most of the different carbonate sources of $\delta^{13} \mathrm{C}$ differ by more than $7 \%$ o the use of FTIR for such task is valid and much more applicative owing to the procedure's simplicity and mobility potential compared to the MS and other technologies such as CRDS lasers.

\section{ACKNOWLEDGMENT}

This work was funded by the Yovalim water cooperation LTD. and the Israeli Water Commission.

\section{REFERENCES}

[1] W. G. Mook, "Environmental isotopes in the hydrological cycle," Tech. Doc. Hydrol, vol. 1, pp. 1-291, 2000.

[2] J. D. Rimstidt, Geochemical Rate Models: An Introduction to Geochemical Kinetics, Cambridge University Press, 2013.

[3] E. Schauble, "Applying stable isotope fractionation theory to new systems," Rev. Mineral. Geochemistry, vol. 55, p. 65, 2004

[4] J. Hoefs, Stable Isotope Geochemistry, 2015.

[5] I. D. Clark and B. Lauriol, "Kinetic enrichment of stable isotopes in cryogenic calcites," Chem. Geol., vol. 102, pp. 217-228, 1992.

[6] W. G. Mook, Environmental Isotopes in the Hydrological Cycle, Chapter 7: Natural abundance of the stable isotopes of $\mathrm{C}, \mathrm{O}$ and $\mathrm{H}$, 2000.

[7] U. Brand, K. Azmy, E. Griesshaber, M. A. Bitner, A. Logan, M Zuschin, E. Ruggiero, and P. L. Colin, "Carbon isotope composition in modern brachiopod calcite: A case of equilibrium with seawater?" Chem. Geol., Vol. 411, pp. 81-96, 2015.

[8] Z. Yu, X. Wang, C. Zhao, and H. Lan, "Carbon burial in Bosten lake over the past century: Impacts of climate change and human activity," Chem. Geol., vol. 419, pp. 132-141, 2015.

[9] E. A. Bruns, V. Perraud, A. Zelenyuk, M. J. Ezell, S. N. Johnson, Y. Yu, D. Imre, B. J. Finlayson-Pitts, and M. L. Alexander, "Comparison of FTIR and particle mass spectrometry for the measurement of particulate organic nitrates," Environ. Sci. Technol., vol. 44, pp. 10561061, 2010.

[10] R. Wehr, S. Kassi, D. Romanini, L. Gianfrani, "Optical feedback cavity-enhanced absorption spectroscopy for in situ measurements of the ratio $13 \mathrm{C}: 12 \mathrm{C}$ in $\mathrm{CO}_{2}$, , Appl. Phys. B., vol. 92, pp. 459-465, 2008.

[11] M. Woelk, "Simple, real-time measurement of stable isotope ratios in $\mathrm{H}_{2} \mathrm{O}$ and $\mathrm{CO}_{2}$," vol. 94085 , p. 6, 2008.

[12] R. N. Zare, D. S. Kuramoto, C. Haase, S. M. Tan, E. R. Crosson, and N. M. R. Saad, "High-precision optical measurements of $13 \mathrm{C} / 12 \mathrm{C}$ isotope ratios in organic compounds at natural abundance," in Proc. Natl. Acad. Sci., USA, vol. 106, pp. 10928-10932, 2009.

[13] A. V. Pelt, Real-Time Atmospheric Monitoring of Stable Isotopes and Trace Greenhouse Gases, 2008.

[14] N. A. Sheffer, M. Cohen, E. Morin, T. Grodek, A. Gimburg, E. Magal, H. Gvirtzman, M. Nied, D. Isele, and A. Frumkin, "Integrated cave drip monitoring for epikarst recharge estimation in a dry Mediterranean area, Sif Cave, Israel," Hydrol. Process., vol. 25, pp. 2837-2845, 2011.

[15] T. Dolgov, "Evaluation of soil preservation treatments on cave drip quality and quantity in the Sif Cave," Jud. Sameria Res. Stud., vol. 21, pp. 319-332, 2012.

[16] P. Rodríguez-Escales, A. Folch, G. Vidal-Gavilan, and B. M. van Breukelen, "Modeling biogeochemical processes and isotope fractionation of enhanced in situ biodenitrification in a fractured aquifer," Chem. Geol., vol. 425, pp. 52-64. 2016.

[17] I. Litvak, Y. Anker, J. Wuelfken, and H. Cohen, "In-situ 13 C / 12 C ratio analysis in water carbonates using FTIR," Agil. Technol. Appl. Note, Environ., pp. 1-6, 2017. 
[18] J. Mohn, M. J. Zeeman, R. A. Werner, W. Eugster, and L. Emmenegger, "Continuous field measurements of delta(13)C-CO(2) and trace gases by FTIR spectroscopy," Isotopes Environ. Health Stud., vol. 44, pp. 241-51, 2008.

[19] D. W. T. Griffith, I. Jamie, M. Esler, S. R. Wilson, S. D. Parkes, C. Waring, and G. W. Bryant, "Real-time field measurements of stable isotopes in water and $\mathrm{CO}_{2}$ by Fourier transform infrared spectrometry," Isotopes Environ. Health Stud., vol. 42, pp. 9-20, 2006.

[20] S.N. Vardag, S. Hammer, M. Sabasch, D. W. T. Griffith, I. Levin, "First continuous measurements of $818 \mathrm{O}-\mathrm{CO}_{2}$ in air with a Fourier transform infrared spectrometer," Atmos. Meas. Tech., vol. 8, pp. 579$592,2015$.

[21] C. G. Ruaux, P. C. Carney, J. S. Suchodolski, and J. M. Steiner, "New IUPAC guidelines for the reporting of stable hydrogen, carbon, and oxygen isotope-ratio data," J. Res. Natl. Inst. Stand. Technol., vol. 100, p. 285,1995

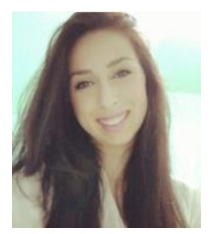

Ira Litvak is a Ph.D. student at the Melbourne University Department of Infrastructure Engineering. She Holds B.Sc. and M.Sc. (Summa Cum Laude) in Chemical engineering from the Ariel University. She worked at as a research assistant inc in the department of environmental studies. Her thesis work was focused on evaluation of FTIR spectroscopy for stable isotopes of in-situ analyses. ratio analysis in environmental research for the purpose

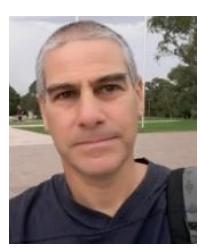

Yaakov Anker holds a B.Sc. in earth sciences and M.Sc. in geochemistry from the Institute of Earth Sciences in the Hebrew University in Jerusalem. He has a Ph.D. from the geophysics and planetary sciences Department and he did his post doc as manager of the Remote Sensing Laboratory both at the Tel Aviv University. At present he is a senior lecturer in the Department of Chemical and Material Engineering at the Ariel University and a senior researcher in the Environmental Department of the Eastern Israel Regional R\&D Center. In recent years he has focused on wastewater and energy issues, including: upgrading of obsolete wastewater treatment facilities, Biological Integrative Pollution Prevention \& Control (Bio-IPPC) systems, energy production from biological wastes and residual biomass, Zero emissions "pseudo traditional" charcoal production system, transformation of aquatic biomass into fuel, transformation of wastewater sludge into electrical energy, sustainable supply of electrical energy to isolates areas.

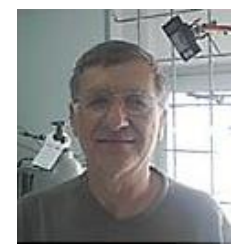

Haim Cohen is a radiation chemist who served for over 35 years as a senior group leader at the Negev Nuclear Research Center in Dimona, Israel. Today Haim is an emeritus professor in the Department of Biological Chemistry (Faculty of Natural Sciences) at Ariel University, and adjunct professor in the Department of Chemistry at Ben-Gurion University of the Negev in Beer Sheba, Israel. Prof. Cohen's research involves mechanisms of radical reactions initiated by ionizing radiation, with a specialization in radiation damage to systems, as a result of exposure to ionizing radiation (beta and gamma). He is a member of the American Chemical Society and Israel Chemical Society, and serves on the Board of Directors of the PCCP (Physical Chemistry and Chemical Physics) Journal of the Royal Society of Chemistry. 